\title{
PERAN MODEL BRAIN-BASED LEARNING PADA PEMBELAJARAN SISTEM SARAF DALAM MENINGKATAN LITERASI SAINS SISWA
}

\author{
Kuni Saadah $^{1}$, Wiwi Isnaeni ${ }^{2}$ \\ ${ }^{1,2}$ Universitas Negeri Semarang - Kampus Sekaran, Kelurahan Sekaran, Kecamatan \\ Gunung Pati 50229
}

\begin{abstract}
Literasi sains merupakan suatu kemamuan siswa dalan mengidentifikasi pertanyaan guna memperoleh pengetahuan yang baru. Penelitian ini bertujuan untuk mengetahui efektivitas model Brain-Based Learning dalam peningkatan literasi sains siswa pada pembelajaran sistem saraf. Desain penelitian ini yang digunakan adalah Pre-Exsperimental Designs dengan bentuk One-Group Pretest-Posttest Design. Pengambilan sampel menggunakan teknik Purposive Sampling Data yang diambil adalah kemampuan berpikir kritis siswa, rasa ingin tahu siswa, tanggapan siswa, dan tanggapan guru mengenai keterlaksanaan pembelajaran. Instrumen yang digunakan berupa soal pretest posttest, lembar observasi dan rubrik penilaian kemampuan afektif serta psikomotorik siswa, angket tanggapan siswa, dan lembar wawancara tanggapan guru. Pengumpulan data dilakukan dengan menggunakan metode tes, observasi dan angket. Hasil belajar ranah kognitif dianalisis ketuntasan klasikal hasil belajarnya dan uji N-gain. Hasil belajar afektif dan psikomotorik serta tanggapan siswa dianalisis secara deskriptif kuantitatif, sedangkan tanggapan guru dianalisis secara deskriptif kualitatif. Analisis data ditentukan menggunakan aplikasi Microsoft excel. Kemampuan berpikir kritis siswa pada kelas XI MIA 2 hasil uji N-Gain 83,3\% dan pada kelas XI MIA $375 \%$. Capaian tersebut termasuk dalam kategori tinggi dengan indikator siswa memperoleh nilai $\geq 70$. Rasa ingin tahu siswa kelas XI MIA 2 75\% dan pada kelas XI MIA 3 83,3\% siswa capaian tersebut termasuk dalam kategori tinggi. Model Brain-Based Learning dapat mencapai indikator keefektifan karena terdapat keberhasilan dan keterpautan model Brain-Based Learning terhadap kemampuan berpikir kritis dan rasa ingin tahu siswa. sehingga dapat disimpulkan bahwa Model Brain-Based Learning efektif untuk peningkatan literasi sains siswa.
\end{abstract}

Kata kunci: Literasi Sains, Brain-Based Learning, Sistem Saraf

Universitas Negeri Semarang

Email: kunisaadah54@gmail.com
(C)2019 Universitas Islam Negeri Walisongo 132

ISSN: 2088-7868, e-ISSN 2502-5708 


\section{PENDAHULUAN}

Perkembangan dan kemajuan dalam bidang sains dan teknologi pada abad 21 dalam kehidupan sosial menuntut masyarakat untuk semakin bekerja keras dan menyeseuaikan diri dalam segala aspek kehidupan mulai dari aspek ekonomi sampai aspek pendidikan. Seperti yang dikatakan oleh Kaur (2013) bahwa tantangan terbesar pada negara saat ini adalah pada bidang pendidikan dimana tidak hanya meningkatkan kualitas pendidikan secara universal namun harus meningkatkan kualitas pendidikan secara luas. Abad 21 merupakan abad yang meminta kualitas dalam segala usaha dan hasil kerja manusia dengan sendirinya abad 21 meminta sumber daya manusia yang berkualitas, yang dihasilkan oleh lembaga-lembaga yang dikelola secara profesional sehingga membutuhkan hasil yang unggulan (Etistika, 2016).

Globalisasi mewariskan rentetan perubahan besar pada tatanan dunia secara menyeluruh. Era ini ditandai dengan proses kehidupan mendunia, kemajuan ilmu pengetahuan dan teknologi, terutama dalam bidang transformasi dan komunikasi serta terjadinya lintas budaya (Fitria, 2013). Era globalisasi menuntut pendidikan berada dalam abad 21 dimana abad 21 juga memiliki tuntutan untuk menghadapi perubahan dalam era reformasi dan globalisasi. Tuntutan tersebut sangat erat kaitanya dengan kemajuan ilmu pengetahuan khususnya dalam bidang sains. Untuk mendorong kemajuan ilmu pengetahuan dan teknologi kedudukan sains menjadi sangat penting. Hal tersebut didukung oleh Deden (2017) yang menyatakan bahwa pendidikan sains memiliki peran strategis dalam menyiapkan sumber daya manusia yang berkualitas untuk menghadapi era globalisasi, salah satunya adalah bidang biologi.

Biologi merupakan salah satu ilmu pengetahuan yang berkaitan erat dengan kehidupan sehari-hari. Pendidikan sains akan melahirkan siswa yang berpotensi, salah satunya berhasil menumbuhkan potensi kemampuan berpikir kritis dan kemampuan memecahkan masalah. Cara lain untuk memperbaiki kemampuan sains pada siswa yaitu dengan cara menerapkan kurikulum 2013. Rahayu (2014) menyatakan bahwa implementasi Kurikulum 2013 merupakan salah satu upaya reformasi pendidikan secara umum dan pendidikan sains pada khususnya. Literasi sains dapat diartikan sebagai suatu kemampuan siswa dalam mengidentifikasi pertanyaan guna memeperoleh pengetahuan yang baru. literasi sains (IPA) menjadi kebutuhan bagi setiap individu agar memiliki peluang yang lebih besar untuk menyesuaikan diri dengan dinamika kehidupan 
(Suryanto,2012).

Hasil studi Programme for International Student Assessment (PISA) pada tahun 2012 rata-rata nilai komponen literasi sains anak Indonesia adalah 382 berada di bawah skala kemampuan yang menempatkan Indonesia pada peringkat ke-63 dari 64 negara di bawah negara Thailand yang memiliki rata-rata nilai 444 menempati posisi ke-50. PISA merupakan sebuah program penilaian internasional yang dikembangkan dan diikuti oleh negara-negara yang berpartisipasi di dalamnya, dan diselenggarakan dengan sasaran anak-anak usia 15 tahun pada setiap 3 tahun sekali (Deden, 2017).

Hasil studi yang dilakukan oleh PISA menunjukan bahwa literasi sains di indonesia masih tergolong rendah yang disebabkan oleh beberapa faktor diantaranya: 1) pembelajaran yang bersifat terpadu pada guru, 2) rendahnya sikap positif siswa dalam mempelajari sains, dan 3) terdapat beberapa kompetensi dasar yang tidak disukai oleh siswa mengenai konten, proses dan konteks. Lestari (2014) juga mengatakan bahwa salah satu faktor penyebab permasalahan rendahnya literasi sains adalah pembelajaran yang tidak memberikan keluasan kepada siswa untuk memberdayakan potensi otak secara optimal.

Pemanfaatan otak secara optimal dalam proses pembelajaran dapat menggunakan model Brain-Based Learning. Menurut Budiargo (2016), Brain Based Learning merupakan pembelajaran yang sesuai dengan cara otak belajar secara alamiah. Oleh karena itu, perlu dilaksanakan pembelajaran yang melibatkan dua aktivitas otak tersebut. Pembelajaran pemanfaatan otak secara maksimal dapat dilihat dari kemampuan rasa ingin tahu dan berpikir kritis siswa, dimana Kemampuan rasa ingin tahu dan berpikir kritis siswa akan berkembang dengan baik apabila siswa dapat menerima pelajaran biologi. seperti yang di katakan oleh Wicaksono (2014) dalam penelitianya, beberapa variabel yang salah satunya adalah berpikir kritis memiliki peluang besar untuk dapat mempengaruhi hasil belajar kognitif peserta didik.

Hasil penelitian yang dilakukan oleh Wulandari (2014), menyatakan bahwa peningkatan hasil belajar siswa yang memperoleh penerapan desain pembelajaran berbasis Brain-Based Learning lebih baik daripada siswa yang memperoleh pembelajaran dengan menggunakan metode ceramah. Hasil Uji-T menunjukan bahwa model brain-based learning dapat meningkatkan kemampuan berpikir kritis siswa dibanding dengan model pembelajaran yang lainya (Utomo, 2016). Hal ini senada 
dengan hasil penelitian Uzezi (2017) bahwa pendekatan berbasis otak yang digunakan pada penelitianya efektif dalam meningkatkan prestasi belajar siswa. Berdasarkan observasi yang dilakukan di MAN 1 kabupaten semarang pada semester genap 2018/2019 bahwa literasi sains masih tergolong rendah yang ditandai dengan kemampuan rasa ingin tahu dan berpikir kritis siswa. sehingga dilakukan penelitian guna melihat efektifitas model brain-based learning untuk peningkatan literasi sains siswa pada materi sistem saraf.

\section{METODE PENELITIAN}

Penelitian ini dilaksanakan di MAN 1 Semarang J1. Suruh-karanggede Km.2, Suruh, Kec.Suruh, Kab. Semarang Prov. Jawa Tengah. Penelitian akan dilaksanakan pada semester genap tahun ajaran 2018/2019 dengan materi yang disampaikan adalah materi sistem saraf. penelitian ini merupakan penelitian jenis PreExsperimental Designs dengan bentuk One-Group Pretest-Posttest Designs. Populasi dalam penelitian ini adalah kelas XI MIA MAN 1 Kab. Semarang. Pengambilan sampel menggunakan teknik Purposive Sampling dan didapatkan kelas XI MIA 2 (32 siswa) dan XI MIA 3 (33 siswa) keduanya sebagai kelas eksperimen. Pengumpulan data dilakukan dengan menggunakan metode tes, observasi dan angket Instrumen dalam penelitian ini berupa kisi-kisi dan soal pretest posttest, lembar observasi dan rubrik penilaian kemampuan afektif serta psikomotorik siswa, angket tanggapan siswa, dan lembar wawancara tanggapan guru. Prosedur penelitian ini terdiri atas tahap persiapan, tahap penelitian dan tahap akhir. Tahap persiapan meliputi observasi permasalahan, memilih subyek penelitian, menyusun perangkat pembelajaran, dan membuat instrumen penelitian. Tahap penelitian meliputi tes awal, melakukan proses belajar mengajar, mengamati sikap dan psikomotorik siswa, dan memberikan tes akhir. Tahap akhir penelitian meliputi analisis data hasil penelitian, membahas hasil penelitian, merumuskan kesimpulan, dan saran. Hasil belajar ranah kognitif dianalisis ketuntasan klasikal hasil belajarnya dan uji N-gain. Hasil belajar afektif dan psikomotorik serta tanggapan siswa dianalisis secara deskriptif kuantitatif, sedangkan tanggapan guru dianalisis secara deskriptif kualitatif. Pengujian hasil data ini menggunakan aplikasi Microsoft excel. 


\section{HASIL DAN PEMBAHASAN}

Dari hasil penelitian yang telah dilakukan peneliti diperoleh sebuah data yang dapat dinyatakan bahwa model Brain-Based Learning efektif terhadap literasi sains siswa pada pembelajarn sistem saraf di MAN 1 Kabupaten semarang. Data tersebut berupa data utama dan data pendukung, data utama terdiri dari data hasil kemampuan berpikir kritis siswa, data hasil kemampuan rasa ingin tahu siswa, dan hasil tanggapan siswa serta tanggapan guru sedangkan data pendukung terdiri data yang diperoleh dari hasil penilaian kelas diantaranya adalah nilai hasil presentasi siswa, nilai hasil karya siswa berupa gambar, dan nilai lembar diskusi siswa.

Kemampuan awal berpikir kritis siswa diukur menggunakan soal pilihan ganda, berdasarkan analisis hasil kemampuan awal berpikir kritis siswa diketahui bahwa ratarata kemampuan awal berpikir kritis siswa perolehan rerata kelas XI MIA 2 51,66 dan rerata kelas XI MIA 3 52,88 dan masih dikategorikan rendah. Rerata nilai hasil akhir kemampuan berpikir kritis siswa adalah kelas XI MIA 2 87,05 dan kelas XI MIA 3 85,58. dari hasil tersebut dapat dinyatakan bahwa kemampuan berpikir kritis siswa setelah diberi perlakuan model Brain-Based Learning lebih baik dibandingakan dengan kemampuan awal berpikir kritis siswa sebelum diberi perlakuan model Brain-Based Learning.

Analisis hasil kemampuan berpikir kritis siswa dilakukan untuk mengetahui perbedaan hasil kemampuan berpikir kritis siswa sebelum diberi perlakuan model Brain-Based Learning dan setelah pembelajaran diberi perlakuan model Brain-Based Learning. Hal tersebut sesuai dengan penelitian yang dilakukan oleh kumala dkk di tahun 2018 mengenai penggunaan model Brain-Based Learning pada ketramilan berpikir kritis siswa untuk pembelajaran IPA. dapat disimpulkan bahwa pada penelitian tersebut terdapat perbedaan antara pembelajaran yang menggunakan model Brain-Based Learning dengan model lainya. Model Brain-Based Learning dapat digunakan sebagai model yang bervariatif (Kumala, 2018). Indikator keefektivan hasil tes adalah apabila $\geq$ $75 \%$ siswa memperoleh nilai $\geq 70$ dengan kategori tinggi. Data perbandingan ketuntasan hasil belajar siswa antara pretest dan posttest disajikan pada Tabel 1.

Tabel 1. Perbandingan ketuntasan hasil kemampuan berpikir kritis siswa

\begin{tabular}{ccc}
\hline Perlakuan & XI MIA 2 & XI MIA 3 \\
\hline Pretest & $9,09 \%$ & $8,33 \%$ \\
Posttest & $88,88 \%$ & $86,11 \%$ \\
\hline
\end{tabular}


Berdasarkan tabel 1. dapat disimpulkan bahwa terdapat perbedaan hasil kemampuan berpikir kritis siswa sebelum dan sesudah diberi perlakuan model BrainBased Learning. Analisis selanjutnya adalah menggunakan uji N-Gain guna untuk mengetahui apakah terdapat peningkatan terhadap literasi sains siswa yang dilihat dari kemampuan berpikir kritis siswa sebelum dan sesudah diberi perlakuan model BrainBased Learning. hasil uji N-gain dapat dilihat pada tabel 2.

Tabel 2. Hasil uji N-Gain

\begin{tabular}{ccc}
\hline Kateogi & XI MIA 2 & XI MIA 3 \\
\hline Tinggi & $83,3 \%$ & $75 \%$ \\
Sedang & $13,8 \%$ & $25 \%$ \\
Rendah & $2,7 \%$ & $0 \%$ \\
\hline
\end{tabular}

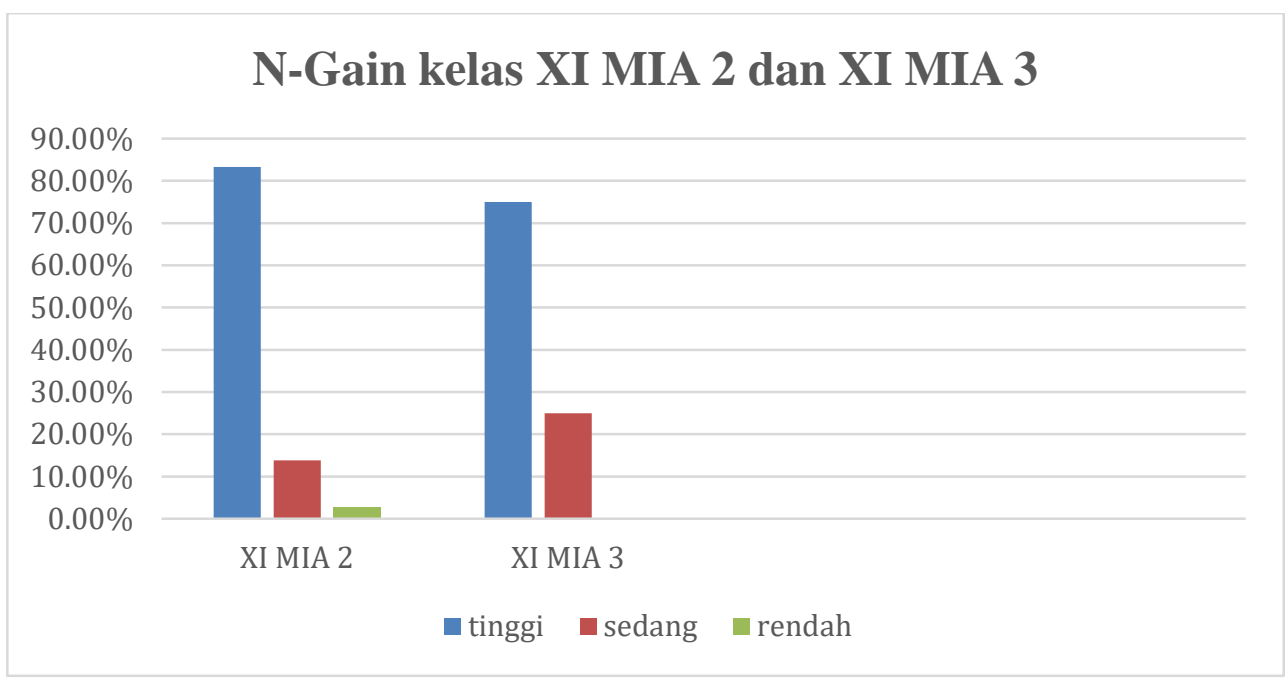

Gambar 1 Hasil uji N-Gain kelas XI MIA 2 dan kelas XI MIA 3

Berdasarkan Tabel 2. dapat dinyatakan bahwa model Brain-Based Learning dapat meningkatkan literasi sains dan rasa ingin tahu siswa melalui hasil belajar siswa. Dengan demikian dapat dikatakan bahwa Penerapan pendekaran model Brain-Based Learning dapat meningkatkan presentasi belajar siswa hal tersebut juga diungkapkan oleh mekarina dalam penelitianya Mekarina (2017) menyatakan bahwa penerapan pendekatan pembelajaran berbasis otak dapat meningkatkan prestasi belajar siswa.

Kemampuan berpikir kritis siswa berdasarkan nilai akhir kemampuan berpikir kritis siswa pada kedua kelas menunjukan bahwa kedua kelas juga masih memiliki kemampuan yang sama dan mengalami peningkatan nilai. Sholihat (2017) menyatakan bahawa hasil belajar siswa yang menggunakan model Brain-Based Learning mengalami 
peningkatan disetiap siklusnya sehingga dapat dikatakan bahwa model Brain-Based Learning efektif untuk diterapkan dalam sebuah pembelajaran (Niswani, 2016). Hal tersebut dikarenakan adanya perlakuan yang diberikan pada kedua kelas tersebut sebelum diberikan posttest.

Perlakuan yang diberikan pada saat proses pembelajaran berlangsung adalah prose pembelajaran menggunakan model brain based learning yang memiliki beberpa tahapan dan tahapan tersebut memberikan efek terhadap kemampuan berpikir kritis siswa diantaranya adalah pada tahap elaborasi pada tahap ini siswa diberi kesempatan untuk menyortir, menyelidiki, menganalisis dan menguji serta memperdalam pembelajarn sehingga menyebabkan kemampuan berpikir kritis siswa mulai dikembangkan dengan memberikan argumen yang logis berdasarkan argumen yang sudah mereka ketahui. seperti yang dikatakan oleh (Khafid, 2016) tahap elaborasi merupakan suatu tahap yang memberikan kesempatan kepada siswa untuk mengemukan hasil analisis yang telah mereka lakukan bersama kelompoknya. Berpikir kritis mencangkup beberapa tindakan kreatif seperti mengajukan pertanyaan, merumuskan hipotesis, dan membuat rencana tentang pengumpulan informasi (Carson,2015).

Berdasarkan aktivitas siswa yang diamati pada saat diskusi sebagian besar siswa memperlihatkan kemampuan mereka dalam berdiskusi diantaranya adalah selalu menanyakan apa yang mereka tidak tahu dan selalu mecari tahu informasi melalui buku selain itu keaktifan mereka diperlihatkan melalui argumen dan berpikir kritis dalam bertanya sehingga diskusi menjadi lancar. Strategi pembelajaran yang menggunakan pertanyaan, diskusi kelas, belajar mandiri maka akan menciptakan suatu pemikiran induktif dan deduktif serta membuat siswa menjadi berpikir lebih kritis (Seechalio,2017). Maka dapat dikatakan bahwa pada saat diskusi kemampuan berpikir kritis siswa pun muncul dan berkembang. Hal tersebut terjadi karena pada saat diskusi siswa dapat menguasai konsep dengan baik, cenderung aktif dan berpikir kritis dalam bertanya serta berargumen dengan teman sekelompoknya (Lezy, 2017).

Kemampuan berpikir kritis tidak hanya tercipta pada tahap elaborasi saja namun pada tahap pra-pemaparan, tahap persiapan, dan hampir pada semua tahap model BrainBased Learning terdapat aktivitas yang menciptakan kemampuan berpikir kritis siswa. Pada tahap pra-pemaparan guru memberikan penjelasan secara garis besar apa yang akan dipelajari dan memberikan beberapa pertanyaan berupa permasalahan yang terjadi 
pada sistem saraf kepada siswa sehingga kemampuan berpikir kritis siswa muncul hal tersebut dikatakan oleh Dini (2017) pada penelitianya membuktikan bahwa pada saat tahap guru peneliti memberikan pertanyaan permasalahan kepada siswa presentase kemampuan berpikir kritis siswa secara klasikal mengalami peningkatan.

Pada tahap persiapan guru memberikan fasilitas guna untuk memberikan suatu pancingan agar siswa mampu bertanya dan memunculkanrasa ingin tahu serta berpikir kritisnya dengan guru menampilkan foto para ilmuan yang berkaitan dengan materi sistem saraf disinilah kemampuan berpikir kritis dan rasa ingin tahu siswa muncul dengan melatih siswa untuk bertanya. aktivitas menanya pada kegiatan suatu pembelajaran jika tidak dilatih maka akan mengurangi ketrampilan bertanya siswa sehingga kemampuan berpikir kritis dan rasa ingin tahu siswa pun akan menjadi rndah hal ini seperti yang dikatakan oleh Usman (2017) pertanyaan dapat menantang siswa untuk memunculkan kemampuan berpikir kritis dan membantunya dalam mengklarifikasi konsep dan problem yang berhubungan dengan pelajaran yang sedang dilakukan.

Pembelajaran yang dilakuakan adalah pembelajaran yang menggunakan model Brain-Based Learning dimana fungsi otak siswa dan perananya dalam pembelajaran dilibatkan. Model Brain-Based Learning merupakan salah satu pembelajaran dan pendekatan yang bsesuai dengan cara berpikir otak siswa serta mampu smenjadikan siswa aktif mengkontruksi pengetahuan (Prayogi, 2017). Pembelajaran berbasis otak membantu memfasilitasi pembelajaran yang bermakna melalui otak alami (Salem,2017). Selain itu pembelajaran berbasis otak memberikan peluang kepada siswa untuk memaksimalkan transfer pengetahuan, dan penyampaian informasi yang mereka dapatkan ketika dalam sebuah pembelajaran hal ini sesuai dengan yang disampaikan oleh Bilal (2006) bahwa teori belajar berbasis otak, otak tersebut berfokus pada konsepkonsep yang menciptakan peluang untuk memaksimalkan, transfer pengetahuan, pencapaian, dan penyimpanan informasi, sehingga kemampuan berpikir kritis siswa menjadi meningkat akibat dipengaruhi oleh keadaan emosianl siswa.

Berpikir kritis termasuk dalam berpikir tingkat tinggi dan mempunyai kemampuan rasa ingin tahu yang begitu tinggi. kemampuan berpikir kritis merupakan pemikiran yang bersifat selalu ingin tahu terhadap suatu permasalahan yang mendalam (Septy, 2015). Berpikir kritis termasuk dalam berpikir tingkat tinggi dan mempunyai 
kemampuan rasa ingin tahu yang begitu tinggi. berpikir kritis merupakan cara berpikir tentang subjek, konten, atau masalah yang mampu meningkatkan kualitas pemikiranya dengan terampil (Nawawi, 2018). Fini (2015) menyatakan bahwa berpikir kritis merupakan satu konsep penting yang terlibat dalam dunia pendidikan selain itu berpikir kritis menurut Nold (2017) melibatkan banyak hal diantaranya mengumpulkan informasi, memproses informasi dengan cara mengidentifikasi, menganalisis, mensistesis, dan mengevaluasi. Perbandingan kemampuan berpikir kritis siswa sebelum dan sesudah diberi perlakuan model Brain-Based Learning dapat dilihat dari nilai awal kemampuan berpikir kritis siswa sebelum siswa diberi perlakuan model Brain-Based Learning dan nilai akhir kemampuan berpikir kritis setelah siswa diberi perlakuan model Brain-Based Learning.

Kemampuan rasa ingin tahu siswa diambil dengan cara pengamatan terhadap aktivitas siswa saat dalam proses pembelajaran. dimana kemampuan rasa ingin tahu siswa dinyatakan tinggi karena pada kedua kelas $\geq 75 \%$ rasa ingin tahu siswa pada kelas XI MIA 2 75\% kategori tinggi dan pada kelas XI MIA 3 83,3 \% dengan kategori tinggi. Kemampuan rasa ingin tahu siswa yang tinggi disebabkan oleh keterlibatan siswa dalam sebuah pembelajaran seperti merumuskan pertanyaan, mendengarkan penjelasan guru dan mau menyimpulkan materi pembelajaran. Hal tersebut menunjukan bahwa pembelajaran berbasis brain-based learning dapat meningkatakan keterlibatan siswa secara aktif dalam sebuah pembelajaran (Khafid, 2016). Ayurek (2013) juga mengatakan bahwa pembelajaran brain-based learning dapat meningkatkan motivasi siswa dalam belajar sehingga berpengaruh positif terhadap hasil belajar siswa. Hasil analisis rasa ingin tahu dapat dilihat pada Ttabel 3.

Tabel 3. hasil analisis ras ingin tahu siswa

\begin{tabular}{ccc}
\hline Kategori & \multicolumn{2}{c}{ Rasa ingin tahu } \\
\cline { 2 - 3 } & XI MIA 2 & XI MIA 3 \\
Tinggi & $75 \%$ & $83,3 \%$ \\
Sedang & $25 \%$ & $16,6 \%$ \\
Rendah & $0 \%$ & $0 \%$ \\
\hline
\end{tabular}




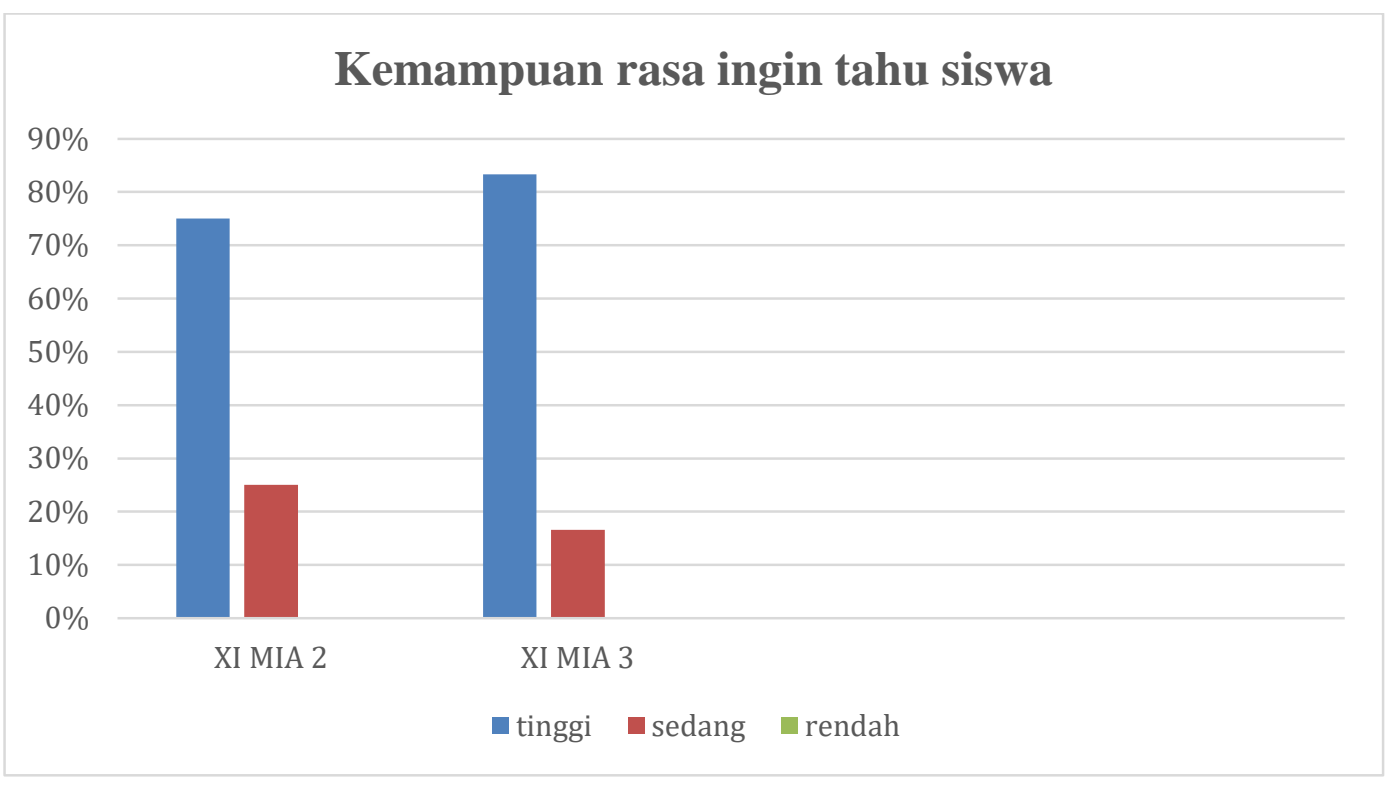

Gambar 2 Hasil analisis rasa ingin tahu siswa

Kemampuan rasa ingin tahu meningkat karena adanya keterlibatan siswa dalam proses pembelajaran dan terdapat perlakuan yang dilakukan oleh guru sehingga memunculkan kemampuan rasa ingin tahu pada siswa diantaranya adalah pada tahap pra-pemaparan guru memberikan penjelasan secara garis besar mengenai sub bab materi yang akan dipelajari dengan menggunakan peta konsep ataupun gambar sehingga tercipta sebuah stimulus yang akan membuat siswa memberikan respon yang baik. Thorndike dalam teorinya mengatakan bahwa hubungan antara stimulus dengan respon akan baik apabila ada kesiapan dalam diri individu (Khafid, 2016). Respon tersebut adalah siswa akan memberikan sebuah pertanyaan kepada guru mengenai apa yang belum ia ketahui disitulah tercipta sebuah rasa ingin tahu pada diri siswa. Hal ini seperti yang dikatakan oleh Alfizah (2016) bahwa rasa ingin tahu siswa dapat memancing siswa dalam melakukan pencarian terhadap hal yang membuatnya menjawab keingin tahuanya dengan cara bertanya. Proses siswa bertanya terjadi pada tahap persiapan karena pada tahap ini gurur memberikan stimulus kepada siswa dengan cara menampilkan gambar atau foto ilmuan yang berkaitan dengan sistem saraf sehingga dan siswa diharuskan untuk bertanya.

Tahap selanjutnya adalah tahap dimana siswa diharuskan merancang dan merencanakan beberapa sumber bahan materi untuk digunakan sebagai sumber materi pada saat pelajaran dan disini kemampuan rasa ingin tahu siswa dimunculkan. Selain itu pada tahap elaborasi siswa diminta un tuk mengerjakan sebuah lembar diskusi, melalui 
lembar diskusi maka siswa akan terbantu untuk menumbuhkan kemampuan rasa ingin tahunya. Diskusi akan membuat siswa untuk melakukan penyelidikan, menganalisis dan mencari tahu jawaban melalui sumber buku lain selain buku pegangan. usaha -usaha yang dilakukan siswa pada proses mencari diantaranya adalah bertanya langsung kepada guru, berdiskusi dengan teman dan mencari beberapa bahan materi dibeberapa sumber (Irna, 2016). pembelajaran Brain-Based Learning sendiri memiliki tujuan untuk menjadikan pembelajaran lebih bermakna dan dengan munculnya kemampuan rasa ingin tahu artinya pembelajaran tersebut bermakna seperti yang dikatakan oleh Millati (2017) bahwa dengan tumbuhnya karakter rasa ingin tahu siswa makan pembelajaran akan lebih bermakna dan lebih bermanfaat bagi siswa.

Aktivitas siswa menggunakan pembelajaran model brain-based learning menunjukan bahwa siswa tersebut memiliki kemampuan rasa ingin tahu yang tinggi hal tersebut dapat dilihat ketika siswa diminta untuk mengerjakan lembar soal diskusi dan mempresentasikan hasil diskusi tersebut didepan kelas bersama satu kelompoknya. untuk mengetahui kemampuan rasa ingin tahu siswa peneliti melakukan observasi terhadap masing-masing siswa dengan 4 indikator diantaranya adalah antusias mencari jawaban, perhatian pada objek yang diamati, antusias pada proses sains, dan menanyakan setiap langkahnya. Model rasa ingin tahu dari daniel berlyne yang dikutip oleh Rowson (2012) meletakkan rasa ingin tahu pada dua sumbu dengan membuat empat dimensi yaitu diantaranya adalah epistemic-cognitif, perceptual-sensory, speciefic-absorption, diversive-ekploration dimana ke-empat dimensi tersebut dituangkan dalam sebuah lembar observasi yang digunakan untuk mengetahui aktivitas siswa dalam kemampuan rasa ingin tahunya.

Sebagian besar siswa menyatakan bahwa mereka tertarik dengan kegiatan pembelajaran yang menggunakan model brain based learning, hal tersebut didukung dengan keterlaksanaan pembelajaran yang dilakukan mendapatkan nilai sangat baik oleh guru pendamping. Selain itu sebagian besar siswa juga menyatakan penjelasan dan cara guru menerapkan pembelajaran berbasis brain-based learning baik, hal ini dikarenakan guru menggunakan bahasa yang mudah dipahami dan komunikatif serta tidak terlepas daru setiap tahapan-tahapan dari model brain based learning. ketertarikan siswa untuk mengikuti pembelajaran berbasis brain-based learning artinya meningkatkan motivasi mereka untuk belajar, sehingga dapat meningkatkan hasil 
belajarnya. Hal ini juga dikatakan oleh Mekarina (2017) bahwa pembelajaran berbasis otak merupakan slah satu pembelajaran inovatif dalam rangka mengoptimalkan fungsi otak, sehingga dapat meningkatkan motivasi dan prestasi belajar siswa. Hasil tanggapan siswa mengenai pembelajaran brain-based learning dapat dilihat pada Tabel 4.

Tabel 4 hasil tanggapan siswa

\begin{tabular}{|c|c|c|c|c|}
\hline \multirow[t]{3}{*}{ Kriteria } & \multirow{2}{*}{\multicolumn{2}{|c|}{$\begin{array}{c}\text { Persentase }(\%) \\
\text { Pertanyaan positif }\end{array}$}} & \multirow{2}{*}{\multicolumn{2}{|c|}{$\begin{array}{c}\text { Persentase }(\%) \\
\text { Pertanyaan negatif }\end{array}$}} \\
\hline & & & & \\
\hline & XI MIA 2 & XI MIA 3 & XI MIA 2 & XI MIA 3 \\
\hline Tinggi & $97,2 \%$ & $97,2 \%$ & $94,4 \%$ & $91,6 \%$ \\
\hline Sedang & $2,7 \%$ & $2,7 \%$ & $5,5 \%$ & $8,3 \%$ \\
\hline Rendah & $0 \%$ & $0 \%$ & $0 \%$ & $0 \%$ \\
\hline
\end{tabular}

Model pembelajaran brain based learning merupakan suatu pembelajaran yang diselerasakan dengan cara otak yang di desain secara alamiah untuk belajar. seperti yang dikatakan oleh virginia (2017) bahwa pendidikan berbasis otak atau pembelajaran model brain-based learning merupakan pembelajaran yang menekannkan bagaimana otak tersebut dapat belajar secara alamiah.

Dalam pembelajaran menggunakan model brain-based learning terdapat beberapa sintak yang harus dilaksanakan sehingga pembelajaran tersebut berjalan dengan lancar sesuai dengan apa yang di inginkan. menurut Faidi (2013:41-42) sintak pembelajaran berbasis otak atau model brain-based learning terdiri dari 7 tahap yaitu tahap pra-pemapaan, tahap persiapan, tahap inisiasi dan akusisi, tahap elaborasi, tahap inkubasi dan memasukkan memori, tahap verivikasi dan pengecekan keyakinan, dan yang terakhir adalah tahap perayaaan dan integrasi.

Adanya perbedaan hasil belajar siswa sebelum dan sesudah proses pembelajaran tidak terlepas dari tahapan-tahapan pelaksanaan model brain-based learning dikelas. Pembelajaran yang didesain berbasi otak merupakan suatu model yang menggunakan belajar konseptual, dimana semua siswa dituntut untuk berperan aktif dalam memecahkan masalah yang sudah disediakan menggunakan lembar diskusi. Perbedaan hasil belajar atau perbedaan titik prestasi akademik siswa yang belajar menggunakan model brain-based learning dan siswa yang belajar tidak menggunakan model brainbased learning terdapat perbedaan yang sangat signifikan (Bilal, 2006). 
Tahap pra pemaparan siswa sudah dituntut untuk memiliki kekampuan rasa ingin tahu yang lebih terhadap materi yang akan dipelajari. pada intinya tahap ini merupakan tahap awal dimana siswa dipersiapkan secara fisik dan mental agar dapat mengikuti proses pembelajaran. hal tersebut didukung oleh Thorndike dalam teorinya yang mengatakan bahwa hubungan antara stimulus dengan respon akan baik apabila ada kesiapan dalam diri individu ( Khafid, 2016). Tahap kedua adalah tahap persiapan dimana fasilitator atau guru dapat menciptakan keingintahuan dan kesenangan bagi siswa. Keingintahuan siswa diciptakan melalui kegiatan guru yang menampilkan foto para ilmuan yang mempunyai berperan dalam ilmu sistem saraf, dan memberikan informasi kepada siswa mengenai pentingnya peran saaf bagi kehidupan manusia didunia, siswa juga diminta untuk menyampaikan rasa keingintahuanya tentang apa yang sudah disampaikan oleh guru.

Pada tahap ketiga yaitu tahap inisiasi dan akuisisi yaitu guru dituntut untuk membantu peserta didik menciptakan koneksi atau neuron-neuron saling berkoneksi. Pada tahap ini kemampuan siswa dalam menciptkan koneksi dibantu dengan guru menugaskan siswa untuk mempersiapkan segala bahan materi yang akan digunakan untuk proses pembelajaran berlangsung sambil siswa menonton beberapa video yang tekait dengan materi sistem saraf. Tahap keempat adalah tahap elaborasi, guru memberikan kesempatan kepada otak siswa untuk menyortir, menyelidiki, menganalisis dan menguji serta memperdalam pembelajaan. kemampuan rasa ingin tahu dan berpikir kritis yang dikembangkan siswa pada tahap ini meliputi ketrampilan dalam memberikan argumentasi yang logis berdasarkan apa yang mereka ketahui.

Pembelajaran dengan melibatkan proses diskusi maka masing-masing kelompok harus mampu mempresentasikan hasil diskusinya sehingga memunculkan rasa ingin tahu siswa. Berdasarkan hasil analisis persentase nilai lembar diskusi siswa memiliki nilai dengan kategori tinggi yaitu pada kelas XI MIA 2 sebesar $100 \%$ siswa dengan kategori tinggi karena mendapatkan skor $\geq 85$ dan kelas XI MIA 3 sebesar 86,11\% dengan kategori tinggi dan sebesar 13,88 dengan kategori baik atau sedang. Tahap kelima, tahap inkubasi dan memasukkan memori ini merupakan waktu istirahat bagi siswa dan waktu mengulang kembali informasi yang sudah didapatkan dengan cara guru menyuruh siswa untuk melakukan relaksasi dengan meminum air putih, siswa diminta untuk mempresentasikan hasil diskusi yang dilanjutkan dengan guru melengkapi materi 
yang telah dibahas saat siswa melakukan presentasi.

Pembelajaan model brain-based learning tidak terlepas dari beberapa penugasan yang harus diselesaikan oleh siswa sehingga membuat siswa menjadi lebih paham lagi mengenai materi apa yang telah dipelajari salah satu contoh tugas tersebut adalah karya cipta berupa gambar. Gambar merupakan salah satu produk hasil karya siswa yang dihasilkah setelah proses pembelajaran berlangsung. Persentase penilaian hasil karya berupa gambar adalah sebesar 88,42 pada kelas XI MIA 2 dengan kategori tinggi dan sebesar 88,42 pada kelas XI MIA 3 dengan kategori tinggi, masing-masing kelompok diskusi membuat satug ambar dengan kreativitas tinggi tanpa penjiplakan dari internet. karya cipta yang dibuat berupa gambar dan tulisan mengenai sistem saraf.

Tahap ke enam adalah tahap verivikasi dan pengecekan kepercayaan mengecek apakah peserta sudah paham dengan materi yang telah disampaikan oleh guru. pengecekan dilakukan dengan cara guru memberikan beberapa pertanyaan mengenai materi sistem saraf yang sudah dipelajarai, selain itu siswa diminta untuk mengerjakan soal posttest guna untuki mengetahui hasil belajar siswa setalah dilakukan poses pembelajaran. Tahap teakhir adalah tahap perayaan dan intergrasi disini siswa diminta menanamkan arti penting dari kecintaanya terhadap belajar. Surkiyah (2013) menyatakan bawa hubungan stimulus dengan respon akan kuat apabila diikuti dengan latihan, dan hubungan ini akan melemah jikalau tidak digunakan atau dihentikan. berdasarkan hal tersebut sangatlah penting bagi guru untuk memberikan kesempatan kepada siswa untuk melatih kembali konsep yang ia dapatkan. Pembelajaran berbasis otak sebagai bagian dari reformasi kurikulum cenderung membuat pembelajaran lebih kontekstual dan melibatkan pelajar dalam pengambilan keputusan, membentuk kelompok kerja sama, menemukan sumber daya dan menerapkan pengetahuan (Awolala, 2011). Tafti (2016) menyimpulkan pada penelitiannya bahwa model pembelajaran berbasis otak memiliki efek yang jauh lebih besar pada pembelajaran dan retensi siswa dibandingkan dengan pembelajaran yang tidak menggunakan model berbasis otak.

Pada penelitian ini masih terdapat beberapa anak yang hasil belajarnya mendapatkan nilai dibawah $\leq 70$ berdasarakan jurnal refleksi yang dituliskan siswa pada lembar diskusi yang diberikan guru, beberapa kendala juga dijumpai selama pembelajaran menggunakan model brain-based learning. selain sumber informasi 
karena tidak boleh menggunakan akses internet oleh pihak sekolah, salah satu kendala yang sering dijumpai adalah keterbatasan waktu, siswa merasa bahwa waktu yang diberikan kurang untuk pembelajaran menggunakan model brain-based learning karena didalam proses pembelajaran brain-based learning membutuhkan waktu yang tidak tegesa-gesa.

\section{SIMPULAN}

Berdasarkan analisis dan pembahasan diperoleh simpulan bahwa pembelajan dengan menggunakan model brain-based learning efektif dalam meningkatkan literasi sains siswa dengan: 1) Hasil tes kemampuan berpikir kritis siswa menggunakan model brain-based learning pada pembelajaran sistem saraf di MAN 1 kab. semarang $\geq 75 \%$ siswa mencapai nilai diatas kriteria kettuntasan minimal yaitu $\geq 70$. 2) terdapat perbedaan kemampuan berpikir kritis siswa sebelum diberi perlakuan dan sesudah diberi perlakuan model brain-based learning. 3) kemampuan rasa ingin tahu siswa $\geq 75 \%$ siswa mencapai nilai diatas kriteria ketuntasan minimal yaitu $\geq 85 \%$. 


\section{DAFTAR PUSTAKA}

Aqil, D.I. 2017. Literasi Sains sebagai Konsep Pembelajaran Buku Ajar Biologi Di Sekolah. Jurnal Pemikiran, Penelitian dan Sains. 5(2):160-171.

Akyurek, E, \& Afacan, O. (2013). Effect of brain-based learning approach on students' motivation and attitudes levels in science class. Mevlana International Journal of Education (MIJE). 3(1), 104-119.

Ameliah, I.H., M. Munawaroh, \& A. Muchyidin. 2016. The Influence Of Curiosity And SelfCinfidence Of Students Toward Ourcome Stydied Mathematichs Grade VII MTS Negeri 1 Cieron. Jurnal Eduma. 5(1).

Awolola, S.A. 2011. Effect Of Brain-Based Learning Strategy On Students Achivement In Senior Secondary School Matematics In Oyo State, Nigeria. Cypriot Journal of Educational Sciences. 91-106.

Bonomo, V. 2017. brain-based learning theory. jurnal of education and human development. Vol.6, No.1.

Budiargo. P, \& A. Sopyan. 2016. Analisis Kemampuan Pemecahan Masalah Matematika Siswa pada Brain Based Learning Ditinjau dari Kecerdasan Emosional. Unnes Journal of Mathematics Education Research. 5 (1).

Carson, S. 2015. Targeting Critical Tinking Skills In A First-Year Undegraduate Research Course. Jurnal Of Microbiologi \& Biologi Education. 148-156.

Duman, B. 2006. the effect of brain-based instruction to improve on students academic achievement in social studies instruction. international coference on engineering education. 23-28.

Faidi, A. 2013. Tutorial Mengajar untuk Melejitkan Otak Kanan dan Kiri Anak. Jogjakarta: DIVA Press.

Fini, I.A., A. Hajibagheri, \& M. A. Hajbaghery. 2015. Critical Thinking Skills In Nursing Students:A Comparison Between Freshmen And Senior Students. Journal Nurs Midwifery Scud. 4(1).

Kaur, J. 2013. Effectivenees Of Brain Based Learning Strategies On Enhancement Of Life Skills Among Primary School Students With Internal And External Locus of Control. International Journal of Advancements In Research \& Technology. 2(6):832.

Khafid, Ainul. 2016. Pengembangan Perangkat Pembelajaran berbasis Brain-Based Learning untuk Meningkatkan Hasil Belajar Siswa. Jurnal Pengkajian Ilmu dan Pembelajaran Matematika dan IPA IKIP Mataram. Vol. 4, No 2

Kumala. F.N., K. Firdayani, \& M.N. Hudha 2018. Keterampilan Berpikir Kritis IPA Siswa SD: Braind Based Learning (BBL) dan Problem Based Learning (PBL). Ejournal Unikama. Vol.8,no.2:53-59.

Lestari, K.E. 2014. Implementasi Brain-Based Learning untuk Meningkatkan Kemampuan Koneksi dan Kemampuan Berpikir Kritis serta Motivasi Belajar Siswa SMP. Jurnal Pendidikan Unsika. Vol.2, No.1.

Lestari, D.D, I. Ansori, \& B. Karyadi. 2017. penerapan model PBM untuk meningkatkan kinerja dan kemampuan berpikir kritis siswa SMA. jurnal pendidikan dan pembelajaran biologi. 1(1):46-54.

Luzyawati, L. 2017. analisis kemampuan berpikir kritis siswa SMA materi alat indera melalui model pembelajaran inquiry pictorial riddle. jurnal pendidikan sains \& matematika. $5(2)$.

Mekarina, M., \& Y.P. Ningsih. 2017. The Effects of Brain Based Learning Approach on Motivation and Students Achievement in Mathematics Learning. international coference on mathematics and science education.

Nawawi, S., \& T.F. Wijayanti. 2018. Pengembangan Asesmen Biologi Berbasis Ketrampilan Berpikir Kritis Terintegrasi Nilai Islam. Jurnal Inovasi Pendidikan IPA. 4 (2), 136-148.

Niswani \& Asdar. 2016. The Effectiveness Of Brain Based Learning Model Using Scientific 
Approach In Mathematics Learning Of Grade Viii Students At Smpn 4 Sungguminasa In Gowa District. Jurnal Daya Matematis. Vol.4, Nomor 3.

Nold, H. 2017. Using Critical Thinking Teaching Methods To Increase Student Success: An Action Research Project. International Journal Of Teaching In Learning Education. 29(1):17-32.

Oviyanti, F. 2013. Tantangan Pengembangan Pendidikan Keguruan di Era Global. Jurnal Pendidikan Islam. Vol.7, Nomor 2.

PISA. 2013. Draft Science Framwork. tersedia di https://www.oecd.org/pisa/pisa [diakses 1412-2018 ].

Prayogi, A., \& A.T. Widodo. 2017. Kemampuan Berpikir Kritis Ditinjau dari Karekter dan Tanggung Jawab pada Model Brain-Based Learning. Unnes Journal of Mathematiccs Education Research. 6(1):89-95.

Rahayu, S. 2014. Menuju Masyarakat Berliterasi Sains: Harapan dan Tantangan Kurikulum 2013. Makalah dipresentasikan pada Seminar Nasional Kimia dan Pembelajarannya 2014. Inovasi Pembelajaran Kimia dan Perkembangan Riset Kimia di Jurusan Kimia FMIPA UM, 6 September 2014. Malang: FMIPA Universitas Negeri Malang.

Rowson, J. (2012). The power of curiosity: how linking inquisitiveness to innovation could help to address our energy challenges. RSA social brain centre, tersedia di https://www.thersa.org/globalassets/pdfs/blogs/rsa-socialbrain-the-power-ofcuriosity.pdf [diakses 11-03-2019].

Sari, A.A.I. 2016. Mengembangkan Rasa Ingin Tahu Dalam Pembelajaran Matematika Nmelalui Penemuan Terbimbing Setting TPS. Jurnal Fkip. Hal 373-382.

Salem, A.A.M.S. 2017. Engaging ESP Students With Brain-Based Learning For Improved Listening Skills, Vocabulary Retention And Motivation. Journal Canadian Center of Science And Education. 10(12):182-195.

Seechaliao,T. 2017. Instructional Strategies To Support Creativity And Innovation In Education. Journal Of Educations And Learning. 6(4):201-207.

Silmi, K,. \& Y. Kusmari. 2017. Menumbuhkan Karakter Rasa Ingin Tahu Siswa Dalam Pembelajaran Sejarah Melalui Media Puzzle. Jurnal Factum. 6(2).

Solihat, A., R.L. Panjaitan, \& D. Djuanda. 2017. Penerapan Model Pembelajaran Brain-Based Learning. Jurnal Pena Ilmiah. Vol 2, No 1

Suyanto. Y.P., H. Susanto, \& S. Linuwih. 2012. Keefektifan Penggunaan Strategi Predic, Observed and Eksplain untuk Meningkatkan Kemampuan Berpikir Kritis dan Kreatif Siswa. Unnes Physics Education Journal. 1(1).

Tafti, M.A, \& M. S. Kadhodaie. 2016. Teh Effects Of Brain-Based Training N The Learning And Retention Of Life Skills In Adolescents. Departement Of Educations \& Psychology. 10(4); 140-144.

Usman, S.M.E. Susilowati, \& P. Widiyaningrum. 2017. Analisis Kesesuaian RPP Terhadap Pelaksanaan Pembelajaran Biologi Dalam Mengembangkan Ketrampilan Berpikir Kritis Siswa. Jurnal Of Innovative Science Education.(6) 2.

Utomo, D.H. 2016. Brain Based Learning: Effects Model A-Car In Critical Thinking Skills. International Conference On Geograpy And Education. Vol 79:339-343.

Uzezi, J. G., \& K. J. Jonah. 2017. Effectiveness Of Brain-Based Learning Strategy On Students Academic Achivement, Attitude, Motivation And Knowledge Retention In Electrochemistry. Journal Of Education, Society And Behavioural Science. 21(3):1-13.

Wijaya. E.Y., D.A.Sudjimat, \& A. Nyoto. 2016. Transformasi Pendidikan Abad 21 sebagai Tuntutan Pengebangan Sumber Daya Manusia di Era Global. Jurnal Prosiding Nasional Pendidikan Matematika 2016.vol 1: hal 263.

Wulandari, D.A. 2014. Brain-Based Learning untuk Meningkatkan Kemampun Berpikir Kritis dan Hasil Belajar Siswa. Chemistry In Education. 3(1)

Wicaksono, A.G.C. (2014). Hubungan Keterampilan Metakognitif dan Berpikir Kritis terhadap 
Hasil Belajar Kognitif Siswa SMA pada Pembelajaran Biologi dengan Strategi Reciprocal Teaching. Jurnal Pendidikan Sains, 2(2), 85-92.

Yustan, S., N. Widodo, \&Y. Pantiwati. 2015. peningkatan kemampuan berpikir kritis dengan pembelajaran berbasis scientific approach siswa kelas X SMA panjura malang. jurnal pendidikan biologi indonesia. 1(2):240-254 